Article

\title{
Black Carbon as a Source of Trace Elements and Nutrients in Ice Sheet of King George Island, Antarctica
}

\author{
Vyacheslav Polyakov 1,*(D), Evgeny Abakumov ${ }^{1}$ and Bulat Mavlyudov ${ }^{2}$ \\ 1 Department of Applied Ecology, Faculty of Biology, St. Petersburg State University, 16th Liniya V.O., \\ 29, St. Petersburg 199178, Russia; e.abakumov@spbu.ru \\ 2 Institute of Geography, Russian Academy of Sciences, Moscow 119017, Russia; bulatrm@bk.ru \\ * Correspondence: st049428@student.spbu.ru or slavon6985@gmail.com; Tel.: +7-9531724997
}

Received: 16 October 2020; Accepted: 14 November 2020; Published: 18 November 2020

\begin{abstract}
Enormous deglaciation in the polar and mountainous regions of the Earth is associated not only with large-scale climatic changes but also with the global transfer of black carbon (BC) microparticles, which accumulate on the surface of glaciers and lead to changes in albedo and the rate of degradation of ice. BC is the product of an incomplete combustion of fossil fuels, volcanic eruptions, and wildfires. The accumulation of organogenic microparticles leads to the formation of cryoconites, which are dust made of a combination of small rock particles and the result of anthropogenic activities (fossil fuel combustion) that play a special role in deglaciation. Here, we describe the content of trace metals and nutrients in accumulation of the BC from glaciers of Fildes Peninsula, King George Island, Western Antarctica. The analysis of trace metals concentrations showed that most of the studied elements $(\mathrm{Cr}, \mathrm{Pb}, \mathrm{Zn}, \mathrm{Ni})$ have a volcanic origin; at the same time, $\mathrm{Cd}$ and $\mathrm{Cu}$ have been accumulated as a result of anthropogenic activity. The content of nutrients in $\mathrm{BC}$ are most similar with Technosols, which forms near the scientific station at King George Island. The particles of BC can be translocated into organisms, which could pose a significant risk for living organisms and humans.
\end{abstract}

Keywords: organic matter; black carbon; cryoconite; nutrients; Antarctica

\section{Introduction}

The Polar Regions affect the climatic balance of the entire globe. An increase in temperature, greenhouse gas emissions, and amount of black carbon (BC) in the atmosphere leads to a reduction in the ice cover of our planet [1-3]. To address this problem, special international groups have been organized to monitor emissions and environmental pollution. The Arctic Monitoring and Assessment Programme (AMAP) established an Expert Group on Short-Lived Climate Forcers (SLCFs) in 2009 with the goal of reviewing the state of science surrounding short-lived climate forcers in the Arctic and recommending scientific tasks to be conducted or promoted by AMAP to increase relevant knowledge and its application to policy-making [4,5]. Arctic warming is a manifestation of global warming; reducing global-average warming will reduce Arctic warming and slow the rate of melting of snow and ice $[6,7]$. Reduction in the emission of carbon dioxide is the backbone of any meaningful effort to mitigate climate forcing [8-10], but it cannot be achieved quickly [5,11]. Therefore, shortening the thawing season is an important intermediate goal, and research on short-lived agents of climate change is necessary to achieve this $[12,13]$. Of special importance are those agents that impose a surface forcing that is capable of triggering regional-scale climate feedbacks pertaining to the melting of sea ice and snow $[5,14]$.

$\mathrm{BC}$ is a short-lived climatic factor-a term referring to a climate-forcing substance that is present in the atmosphere over small time scales (from several days to several years) [5,11]. It is the second-largest 
artificial contributor to global warming and accelerating glacier melting after carbon dioxide [15]. $\mathrm{BC}$ absorbs several hundred times more heat than carbon dioxide [16]. Therefore, globally, reducing emissions of $\mathrm{BC}$ is one of the main tasks in solving the problem of climate change [17]. $\mathrm{BC}$ is formed from an incomplete combustion of fossil fuels and biomass [18,19], mainly in the form of emissions from diesel engines, industrial production processes, and oil and gas production, as well as the combustion of wood and coal, incineration of agricultural waste, and wildfires. The main sources of BC in the northern polar regions (Greenland, Russia, Canada and Svalbard) are wildfires, especially from Asian regions [20]. The second largest source of $\mathrm{BC}$ is the combustion of fossil fuels in Eurasia. In addition to these two sources is industrial pollution, the effects of which have been noted in the North Pole region [21]. The main period of deposition on terrestrial surfaces of BC is late autumn and winter [20].

The Antarctic ice sheet is an integral part of the globe and plays an important role for humanity [22]. The Antarctic ice sheet is an important indicator of climate change and a driver of sea level rise. As their depletion continues to accelerate, Antarctic ice streams contribute about $10 \%$ of the observed global sea level rise [23,24]. According to various estimates, the Antarctic ice contains $80 \%$ to $90 \%$ of the fresh water on the Earth's surface $[25,26]$. The current state of the Antarctic ice sheet is unclear and controversial. Volcanism is concentrated in western Antarctica and is associated with the Antarctic Peninsula. The volcanoes form the Antarctic Volcanic Belt, which can be traced from Ross Island to the Antarctic Peninsula along the coast of Mary Byrd Land and Edsworth Land. Currently, there are more than 800 active volcanoes on Earth, most of which are located in the northern hemisphere. Volcanic eruptions are considered one of the main sources of $\mathrm{BC}$ particle emissions that are accelerating the melting of glaciers [27]. After an eruption, the heavier ash particles quickly settle on the ground, while the lighter ones are suspended in the atmosphere and can be carried over considerable distances [28]. Falling out on territories covered with snow and ice, including Antarctica, volcanic ash increases the absorption of solar radiation, which contributes to the intense melting of snow $[29,30]$. The primary sources of $\mathrm{BC}$ in the southern hemisphere are biomass combustion in Australia, South America, and Africa. The anthropogenic influence of the accumulation of BC in Antarctica has been noted near Palmer Station (USA). BC concentrations in cryoconites reduced with the distance to Palmer station from 16.5 to $1.2 \mathrm{mg} \mathrm{BC}$ and were higher than in other BC studies on snow in natural ecosystems, such as the McMurdo Dry Valleys. That the content of BC increased near the Antarctic station has also been noted in other parts of Antarctica. It has been noted that in addition to the contribution of BC from scientific bases, the combustion of biomass and fossil fuels as well as wildfires occurring in the southern hemisphere could also affect the content of $\mathrm{BC}$ on the surface of glaciers and snow in Antarctica [31].

The Antarctic ecosystem is particularly sensitive to anthropogenic modifications [32]. Ice-free land occupies $<2 \%$ of the continent, but most of the human and terrestrial biological activities are concentrated in these areas [33]. Heavy metals naturally occur in the Earth crust [34-36], and human activities have introduced high loads of these elements into the surficial environment. BC that accumulates in cryoconites can provide a temporally integrated indication of environmental condition and act as a reservoir for metals [21,37-39]. The accumulation of radionuclides in the $\mathrm{BC}$ of cryoconites is also noted. The main source of these radionuclides is the testing of nuclear weapons in the Pacific Ocean. Due to its organic content, cryoconite effectively binds and accumulates impurities contained in melt water, which have an affinity for organic substances, including trace elements, nutrients, and radionuclides [21,40].

The Antarctic Peninsula and adjacent islands have the highest concentration of research stations in Antarctica. In addition, the islands located near the peninsula are those most often visited by tourist boats. The study of the $\mathrm{BC}$ that accumulates on the glaciers of Antarctica is poorly investigated. The study of local sources of pollution is an important contribution to monitoring the vulnerable environment of Antarctica. Thus, the aim of this research was to evaluate the content of trace elements and key nutrients in cryoconites on the Fildes Peninsula on King George Island. To achieve this aim, the following objectives were set: (1) to evaluate the gravimetrical concentrations of key trace 
elements and (2) to identify key nutrients concentration in the cryoconites sampled on the surface Collins Ice Cap.

\section{Materials and Methods}

\subsection{Study Area}

King George Island is the largest of the South Shetland Archipelago, with an area of about $1338 \mathrm{~km}^{2}$. Nearly the entire island is covered with ice. The largest ice-free area is the Fildes Peninsula in the south-west part of the island (Figure 1).

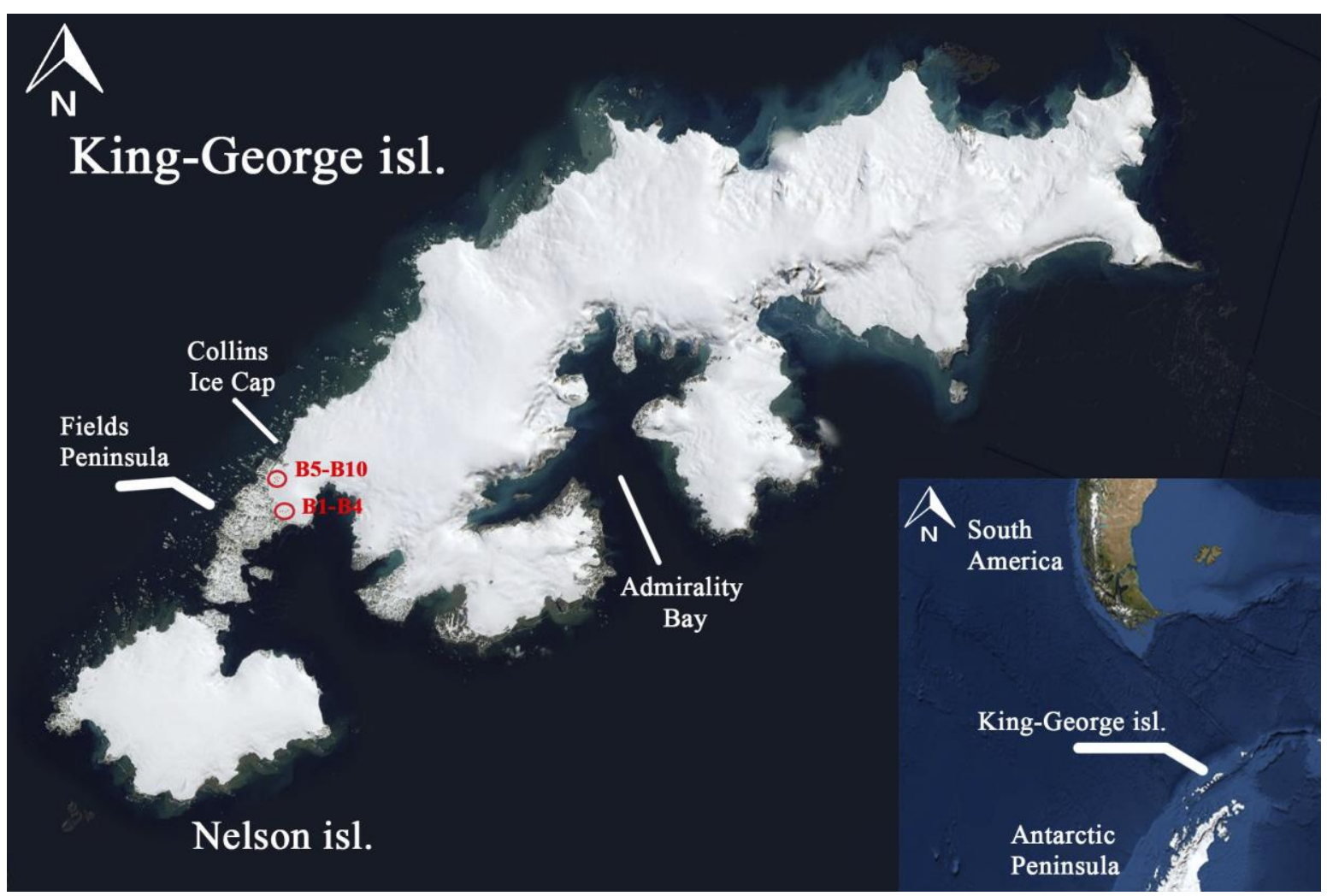

Figure 1. The study area. Fildes Peninsula, King George Island, Antarctica.

The maximum height of the ice caps reaches $700 \mathrm{~m}$. The peninsula consists of volcanic rocks, mainly andesites, basalts, and various tuffs. The climate of Fildes Peninsula is marine. The number of sunshine days is about 100 . The average annual temperature is $-2.8^{\circ} \mathrm{C}$. The annual precipitation is $729 \mathrm{~mm}$. A characteristic feature of West Antarctica is precipitation in the liquid form of water [33,41]. Observations in Admiralty Bay indicate the retreat of the glacier and the reduction of the ice sheet over the past decades. A total of 10 cryoconites samples were taken from the western part of Collins Ice Cap of King George Island, Antarctica (Figure 2). 

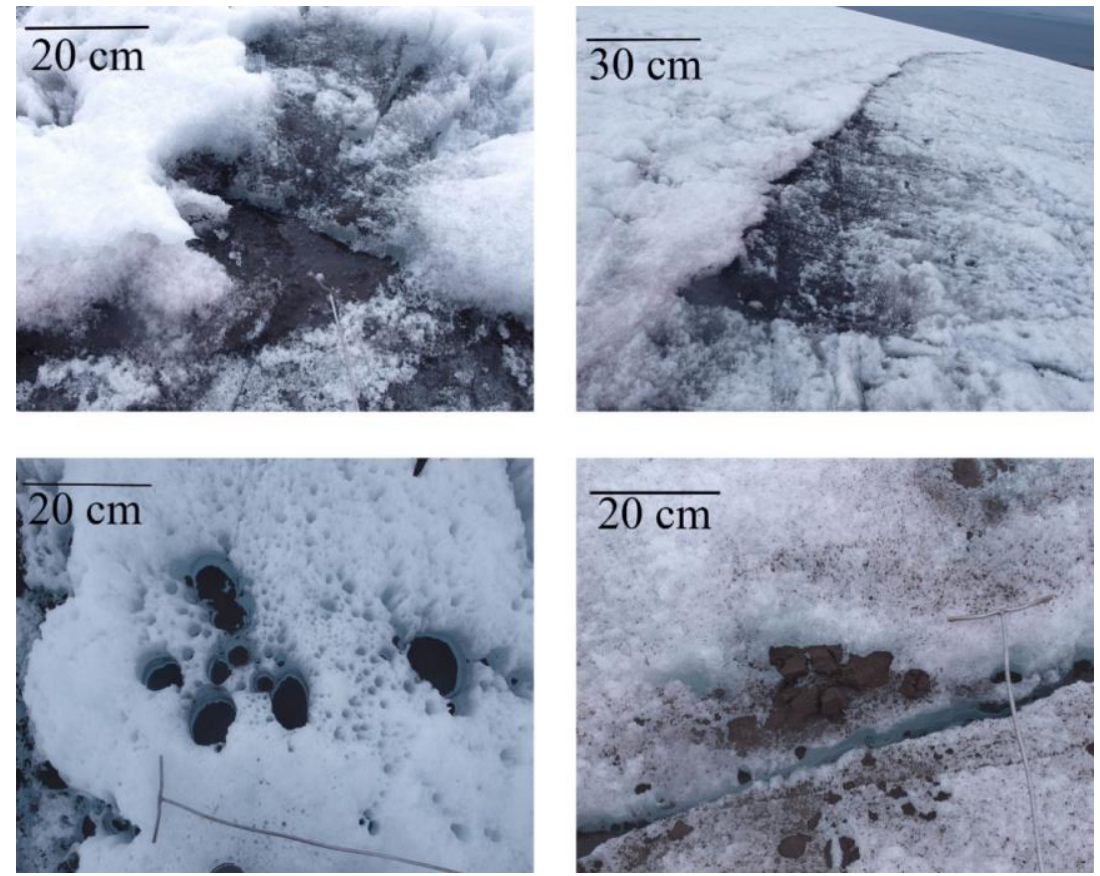

Figure 2. Studied cryoconites from Collins Ice Cap, King George Island, Antarctica.

\subsection{Methology}

Samples were taken during the glaciological surveys in February 2020 from the ice and delivered to the field laboratory. There are several ways to sample BC, depending on the source from which they are taken (snow, ice, or water). We use a small drill to extract $\mathrm{BC}$ from ice; it is important to use only mechanical or electrical devices in order to eliminate an additional source of exhaust gases that could affect study results. After collection, samples are defrosted, the water is filtered, and the filter residue is analyzed. Snow and water analysis are similar to ice analysis. To extract BC from snow, it is necessary to melt the snow and separate the particles of $B C$ from the resulting water by filter. For water samples, it would be filtered to isolate the particles of BC. A standard BC isolation method is described by Hegg et al. [15,42]. Dried samples were investigated at the Department of Applied Ecology of St. Petersburg State University, St. Petersburg. The coordinates of studied cryoconites are presented in Table 1. The origin of studied cryoconites has been investigated during the glaciological survey.

Table 1. Description of the studied cryoconites.

\begin{tabular}{|c|c|c|c|c|}
\hline Sample ID & \multicolumn{2}{|c|}{ Coordinates (S/W) } & Elevation (m) & Origin \\
\hline B1 & $62^{\circ} 10^{\prime} 27.8^{\prime \prime}$ & $58^{\circ} 54^{\prime} 29.7$ & 88 & Volcano \\
\hline B2 & $62^{\circ} 10^{\prime} 27.3^{\prime \prime}$ & $58^{\circ} 54^{\prime} 19.8^{\prime \prime}$ & 103 & Volcano \\
\hline B3 & $62^{\circ} 10^{\prime} 27.7^{\prime \prime}$ & $58^{\circ} 54^{\prime} 13.6^{\prime \prime}$ & 108 & Volcano \\
\hline B4 & $62^{\circ} 10^{\prime} 26.2^{\prime \prime}$ & $58^{\circ} 54^{\prime} 10.6^{\prime \prime}$ & 114 & $\begin{array}{l}\text { Volcano with biogenic } \\
\text { material of ornitogenic origin }\end{array}$ \\
\hline B5 & $62^{\circ} 9^{\prime} 18.4^{\prime \prime}$ & $58^{\circ} 54^{\prime} 20.6^{\prime \prime}$ & 121 & $\begin{array}{c}\text { Volcano with biogenic } \\
\text { material of ornitogenic origin }\end{array}$ \\
\hline B6 & $62^{\circ} 9^{\prime} 15.8^{\prime \prime}$ & $58^{\circ} 54^{\prime} 9.3^{\prime \prime}$ & 130 & $\begin{array}{l}\text { Volcano with biogenic } \\
\text { material of ornitogenic origin }\end{array}$ \\
\hline B7 & $62^{\circ} 9^{\prime} 9.5^{\prime \prime}$ & $58^{\circ} 54^{\prime} 23.1^{\prime \prime}$ & 118 & $\begin{array}{l}\text { Volcano with biogenic } \\
\text { material of ornitogenic origin }\end{array}$ \\
\hline B8 & $62^{\circ} 9^{\prime} 5.6^{\prime \prime}$ & $58^{\circ} 54^{\prime} 30.4^{\prime \prime}$ & 99 & $\begin{array}{c}\text { Volcano with biogenic } \\
\text { material of ornitogenic origin }\end{array}$ \\
\hline B9 & $62^{\circ} 9^{\prime} 6.9^{\prime \prime}$ & $58^{\circ} 54^{\prime} 34.5^{\prime \prime}$ & 98 & Volcano \\
\hline B10 & $62^{\circ} 9^{\prime} 21.8^{\prime \prime}$ & $58^{\circ} 54^{\prime} 48.1^{\prime \prime}$ & 92 & Volcano \\
\hline
\end{tabular}




\subsection{Chemical Analyses}

The contents of carbon, nitrogen, heavy metals, and nutrients were determined. Carbon (C) and nitrogen $(\mathrm{N})$ content were determined using an element analyzer (EA3028-HT EuroVector, Pravia PV, Italy). The content of heavy metals was determined following to the standard ISO 11047-1998 "Soil Quality-Determination of Cadmium (Cd), Cobalt (Co), Copper $(\mathrm{Cu})$, Lead $(\mathrm{Pb})$, Manganese $(\mathrm{Mg})$, Nickel (Ni) and Zinc (Zn) in Aqua Regia Extracts of Soil - Flame and Electrothermal Atomic Absorption Spectrometric" method at Atomic absorption spectrophotometer Kvant 2M (Moscow, Russia) [43]. The content of nitrate and ammonium nitrogen ( $\mathrm{N}-\mathrm{NH}_{4}$ and $\left.\mathrm{N}-\mathrm{NO}_{3}\right)$ took place following the method outlined in [44], using potassium chloride solution. The content of mobile potassium $\left(\mathrm{K}_{2} \mathrm{O}\right)$ and phosphorus $\left(\mathrm{P}_{2} \mathrm{O}_{5}\right)$ was determined by the Kirsanov method [45]. The method is based on the extraction of mobile compounds of phosphorus and potassium from the soil with a solution of $0.2 \mathrm{M} \mathrm{HCl}$.

\subsection{Statistical Analysis}

Statistical data processing and Spearmen's correlation analysis were performed in the Paleontological Statistics (PAST) program software. In our study, we used two statistical analyses to reveal the relationship between the studied components: principal component analysis (PCA) analysis and Spearman's rank correlation. PCA analysis made it possible to conduct a search procedure for variables (components) that explain the variance of multivariate data. Spearman's rank correlation coefficient is a quantitative assessment of the statistical study of the relationship between phenomena, and it is used in nonparametric methods.

\section{Results and Discussion}

\subsection{The Content of Trace Metals in Studied Cryoconites}

The investigated BC samples were analyzed according to the ISO standard [43]. The resulting trace metals content is presented in Table 2.

Table 2. The content of trace metals from the studied cryoconites $\left(\mathrm{mg} \cdot \mathrm{kg}^{-1}\right)$.

\begin{tabular}{ccccccc}
\hline Sample ID & $\mathbf{C u}$ & $\mathbf{P b}$ & $\mathbf{Z n}$ & $\mathbf{C d}$ & $\mathbf{N i}$ & $\mathbf{C r}$ \\
\hline B1 & 6.85 & 3.12 & 13.3 & 0.258 & 6.33 & 4.20 \\
B2 & 9.55 & 3.27 & 16.6 & 0.295 & 6.90 & 4.75 \\
B3 & 7.56 & 1.05 & 14.1 & 0.150 & 6.01 & 2.38 \\
B4 & 15.8 & 5.53 & 23.0 & 0.357 & 8.06 & 5.91 \\
B5 & 20.4 & 6.31 & 27.4 & 0.409 & 8.49 & 5.00 \\
B6 & 22.8 & 8.08 & 30.9 & 0.499 & 9.64 & 7.52 \\
B7 & 19.2 & 6.69 & 27.4 & 0.359 & 8.47 & 4.79 \\
B8 & 21.4 & 4.48 & 28.6 & 0.319 & 7.57 & 3.45 \\
B9 & 11.3 & 1.56 & 18.6 & 0.310 & 6.34 & 5.39 \\
B10 & 6.81 & 0.102 & 10.9 & 0.207 & 5.36 & 1.98 \\
Standard deviation & 6.45 & 2.64 & 7.27 & 0.10 & 1.35 & 1.64 \\
Coefficient of Variation, \% & 45.5 & 65.8 & 34.5 & 31.43 & 18.42 & 36.23 \\
\hline
\end{tabular}

The data obtained indicate the accumulation of trace elements in cryoconites in the Collins Ice Cap. Comparison of the obtained data with other sources of trace elements in Antarctica is presented in Table 3. Through comparison of the obtained concentrations of trace elements with those of soils, bay sediments, and volcanic rocks, it can be concluded that the lowest concentrations are observed in cryoconites [46]. This is presumably associated with different mechanisms of accumulation of trace elements. The origin of cryoconites is associated with atmospheric precipitation, as well as anthropogenic activity in the area. Of the studied elements, $\mathrm{Cd}$ was the closest in concentration to the soils and sediments of Fildes Bay [47]. It accumulates considerably in soils forming on Fildes 
Peninsula. Cryoconites from King George Island have a volcanic origin. From the comparison of obtained concentrations with those of volcanic rocks, we note a decrease in the concentration of $\mathrm{Cu}$ and $\mathrm{Zn}$. At the same time, there is an accumulation of $\mathrm{Cd}$ and $\mathrm{Cr}$, which apparently have an anthropogenic origin. The largest amount of $\mathrm{Cd}$ is present in the areas where Antarctic scientific stations are based $[38,48,49]$.

Table 3. Average content of trace metals in studied cryoconites in comparison with results of other studies $\left(\mathrm{mg}^{\mathrm{kg}}{ }^{-1}\right)$.

\begin{tabular}{ccccccc}
\hline Sampling Site & $\mathbf{C u}$ & $\mathbf{P b}$ & $\mathbf{Z n}$ & $\mathbf{C d}$ & $\mathbf{N i}$ & $\mathbf{C r}$ \\
\hline Cryoconites $^{1}$ & 14.16 & 4.01 & 21.08 & 0.32 & 7.32 & 4.54 \\
Soil from Trinity House Ruins $^{2}$ & 107 & 102 & 148 & $<0.2$ & 37.9 & 72 \\
Soils from Robert Island $^{3}$ & 47.8 & 7.3 & 43.9 & $<0.2$ & 40.4 & 52 \\
Soil from Fildes Bay $^{4}$ & 31 & 23 & 15000 & 0.33 & - & - \\
Soil from O'Higgins Base $^{5}$ & 422 & 282 & 485 & 4.3 & 28 & 65 \\
Sediments King George Island $^{6}$ & 92 & 10.5 & 89 & - & 10.1 & 31 \\
Vulcanic rock King George Island $^{7}$ & 111 & 7.7 & 66 & - & 12.5 & -
\end{tabular}

${ }^{1}$ Mean value of studied BC; ${ }^{2}$ Guerra et al. [48]; ${ }^{3}$ de Lima Neto et al. [38]; ${ }^{4}$ Amaro et al. [47]; ${ }^{5}$ Celis et al. [49];

${ }^{6}$ Santos et al. [37]; ${ }^{7}$ Groeneweg and Beunk [46].

Principal component analysis (PCA) analysis (Figure 3) indicates an accumulation of $\mathrm{Zn}$ and $\mathrm{Cu}$ in cryoconites at Collins Ice Cap. These elements accumulate mainly from the volcanic rocks of the island.

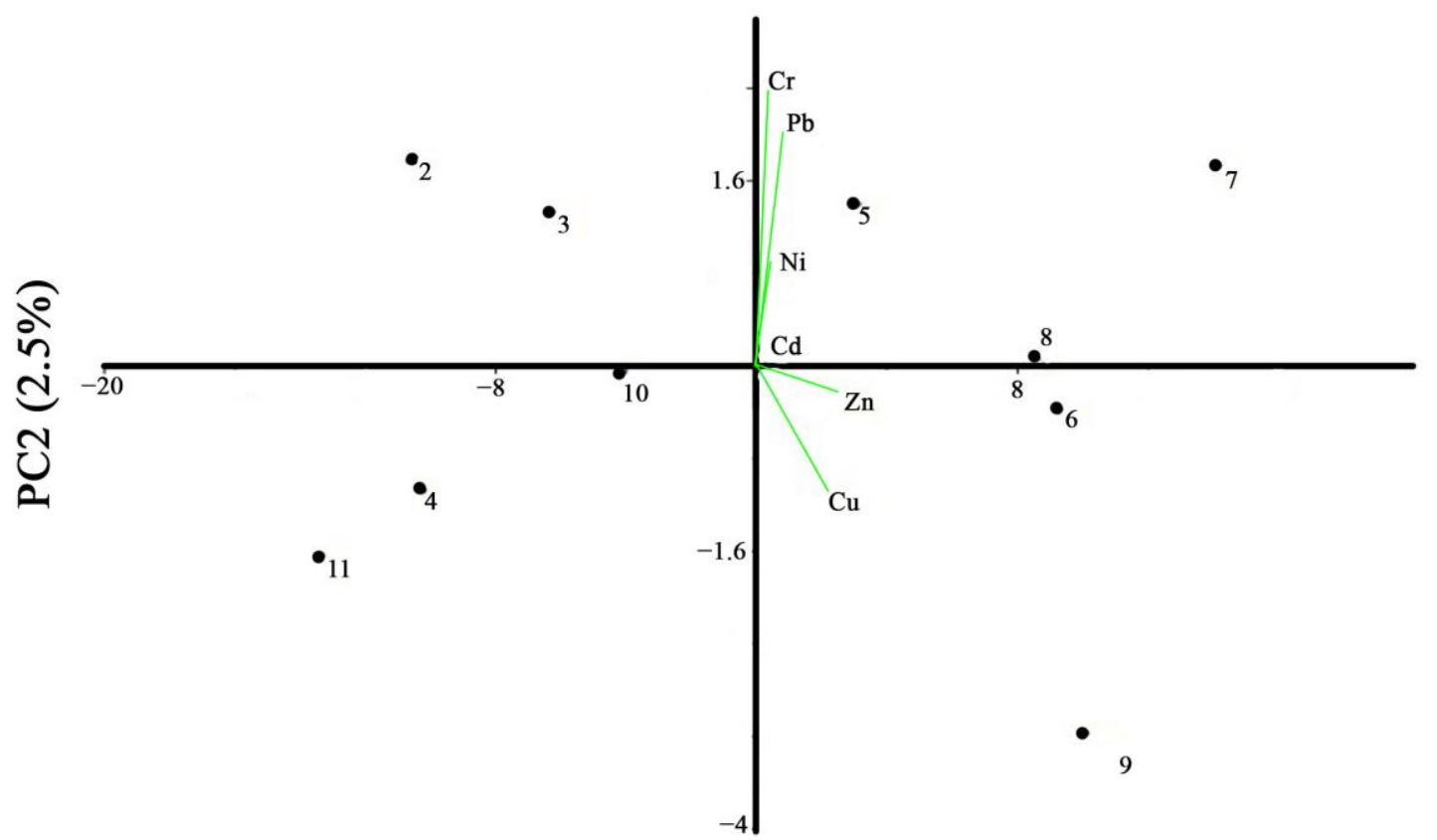

PC1 (96.6\%)

Figure 3. Principal component analysis (PCA) of studied trace metals from Collins Ice Cap.

To identify a statistically significant relationship, Spearmen correlation analysis was performed (Table 4). From the obtained correlation, connection was revealed for $\mathrm{Zn}$ and $\mathrm{Cu}(\mathrm{r}=0.99)$ as well as $\mathrm{Ni}$ and $\mathrm{Pb}(\mathrm{r}=0.98)$. These four elements accumulate mainly during the erosion of volcanic rocks on the island and are associated with atmospheric deposition on glaciers [46]. 
Table 4. Spearmen's correlation of the studied trace metals.

\begin{tabular}{ccccccc}
\hline$p=\mathbf{0 . 9 5}$ & $\mathbf{C u}$ & $\mathbf{P b}$ & $\mathbf{Z n}$ & $\mathbf{C d}$ & $\mathbf{N i}$ & $\mathbf{C r}$ \\
\hline $\mathrm{Cu}$ & 1 & 0.87 & $\mathbf{0 . 9 9}$ & 0.84 & 0.90 & 0.59 \\
$\mathrm{~Pb}$ & & 1 & 0.89 & 0.90 & $\mathbf{0 . 9 8}$ & 0.76 \\
$\mathrm{Zn}$ & & & 1 & 0.85 & 0.92 & 0.64 \\
$\mathrm{Cd}$ & & & & 1 & 0.92 & 0.88 \\
$\mathrm{Ni}$ & & & & & 1 & 0.78 \\
$\mathrm{Cr}$ & & & & & & 1 \\
\hline
\end{tabular}

In Antarctica, the areas most affected by anthropogenic activities are those close to oil reservoirs, power generators, or landfills, or those directly affected by fires $[38,48,50]$. The source of $\mathrm{Cd}$ and $\mathrm{Cu}$ is mostly fuel spills and paintwork in the Antarctic station areas. In comparison with the northern hemisphere, it should be noted that the mountain systems of Tibet are subject to a greater degree of anthropogenic pollution and accumulation of trace elements in cryoconites [51]. As already noted, during the transfer of trace metals, their concentration decreases from the source to the place of deposition. The main periods of deposition of BC, as in the Arctic sector, are periods of high air humidity, Arctic haze, and the monsoon period, at which time there is an active deposition of $\mathrm{BC}$ along with precipitation [52]. Data from the Svalbard Archipelago reveal the anthropogenic origin of Cd and $\mathrm{Pb}$, as well as their high concentration relative to natural elements, which was noted in our study of cryoconites from the Collins Ice Cap. Apparently, cryoconite granules have a peculiar ability to concentrate metals, and they play a special role in the cycle of airborne metal pollutants in the Arctic and Antarctic [21].

Most of the studies related to the pollution of soil and aquatic ecosystems in Antarctica $[21,37,38]$ have shown that pollution is mainly concentrated around scientific stations. Environmental monitoring studies are extremely important for the conservation of the continent's vulnerable plant and animal species. The formation of cryoconites and the accumulation of trace metals in their composition is an additional contribution to the pollution of the vulnerable ecosystem of Antarctica.

\subsection{The Content of Key Nutrients from Studied Cryoconites}

Table 5 shows the nutrient content of BC from the Collins Ice Cap. Accumulation occurs through atmospheric precipitation and rarely via transportation by birds, which do not use the cryoconites as nesting sites [41]. When compared to soils from King George Island, cryoconites were found to accumulate the lower concentration of nutrients. The nutrient content of cryoconites is most similar to that of Technic Cryosol, which is actively exposed to anthropogenic impact.

Table 5. The content of nutrients of black carbon (BC) from Collins Ice Cap.

\begin{tabular}{cccccccc}
\hline Sample ID & $\mathbf{C}, \%$ & $\mathbf{N}, \%$ & $\mathbf{C} / \mathbf{N}$ & $\mathbf{P}_{\mathbf{2}} \mathbf{O}_{5}$ & $\mathbf{K}_{\mathbf{2}} \mathbf{O}$ & $\mathbf{N}-\mathbf{N H}_{\mathbf{4}}$ & $\mathbf{N}_{-} \mathbf{N O}_{3}$ \\
\hline B1 & 0.08 & 0.06 & 1 & 37 & 196 & 119 & 1 \\
B2 & 0.78 & 0.12 & 7 & 40 & 224 & 128 & 1 \\
B3 & 0 & 0.02 & 0 & 118 & 159 & 24 & 1 \\
B4 & 3.92 & 0.53 & 7 & 11 & 375 & 280 & 1 \\
B5 & 5.44 & 0.61 & 9 & 13 & 395 & 306 & 2 \\
B6 & 5.23 & 0.74 & 7 & 18 & 399 & 332 & 2 \\
B7 & 5.32 & 0.56 & 9 & 51 & 318 & 156 & 5 \\
B8 & 3.94 & 0.46 & 8 & 13 & 379 & 170 & 2 \\
B9 & 0.15 & 0.08 & 2 & 66 & 240 & 121 & 1 \\
B10 & 0.04 & 0.05 & 1 & 43 & 171 & 108 & 1 \\
Standard deviation $_{\text {Coefficient of variation, } \%}$ & 2.46 & 0.28 & 3.63 & 32.78 & 97.55 & 99.31 & 1.25 \\
Leptosols $^{1}$ & 99.07 & 86.94 & 71.26 & 79.95 & 34.15 & 56.94 & 73.62 \\
Technic Cryosol $^{1}$ & 7.12 & 0.58 & 12 & 2238 & 1849 & 461 & 155 \\
& 4.64 & 0.41 & 11 & 435 & 465 & 36 & 9 \\
\hline
\end{tabular}


Spearmen correlation was performed to identify statistically significant relationships between nutrients (Table 6). A strong relation was found between $\mathrm{N}$ and $\mathrm{N}-\mathrm{NH}_{4}(\mathrm{r}=0.96)$ and $\mathrm{N}^{-\mathrm{NH}_{4}}$ and $\mathrm{K}_{2} \mathrm{O}$ $(\mathrm{r}=0.97)$. A negative correlation with $\mathrm{P}_{2} \mathrm{O}_{5}$ was noted, which indicates that with a decrease in the content of $\mathrm{P}_{2} \mathrm{O}_{5}$, the content of other nutrients increases. This may be related to the composition of the microbial community that forms in cryoconites.

Table 6. Spearmen's correlation of the studied nutrients.

\begin{tabular}{cccccccc}
\hline $\boldsymbol{p}=\mathbf{0 . 9 5}$ & $\mathbf{C}$ & $\mathbf{N}$ & $\mathbf{C} / \mathbf{N}$ & $\mathbf{P}_{\mathbf{2}} \mathbf{O}_{5}$ & $\mathbf{K}_{\mathbf{2}} \mathbf{O}$ & $\mathbf{N}-\mathbf{N H}_{4}$ & $\mathbf{N}_{-N O_{3}}$ \\
\hline $\mathrm{C}$ & 1 & 0.95 & 0.95 & $\mathbf{- 0 . 5 4}$ & 0.89 & 0.89 & 0.84 \\
$\mathrm{~N}$ & & 1 & 0.84 & $\mathbf{- 0 . 5 9}$ & 0.93 & $\mathbf{0 . 9 6}$ & 0.75 \\
$\mathrm{C} / \mathrm{N}$ & & & & $\mathbf{- 0 . 5 0}$ & 0.78 & 0.78 & 0.81 \\
$\mathrm{P}_{2} \mathrm{O}_{5}$ & & & & 1 & $\mathbf{- 0 . 6 9}$ & $\mathbf{- 0 . 7 4}$ & $\mathbf{- 0 . 2 4}$ \\
$\mathrm{K}_{2} \mathrm{O}$ & & & & & 1 & $\mathbf{0 . 9 7}$ & 0.70 \\
$\mathrm{~N}_{-} \mathrm{NH}_{4}$ & & & & & & 1 & 0.63 \\
$\mathrm{~N}^{-\mathrm{NO}_{3}}$ & & & & & & & 1 \\
\hline
\end{tabular}

The source of phosphorus and nitrogen compounds may be associated with avian activity, as birds are the main source of nutrients in Antarctica. Increasing nutrient content in cryoconites can lead to green vegetation, which absorbs less sunlight than black particles and reduces the rate of deglaciation. According to earlier studies of ornithogenic soils, the content of mobile forms of nutrients is much higher than in cryoconite holes, which is associated with the direct accumulation of nutrients and low indicators of microbiological activity in Antarctic soils. The background nutrient content in the soils of King George Island is higher than that of the cryoconite samples [41]. This distribution of nutrients is associated with the atmospheric accumulation in cryoconites of organomineral substances from the local soils. The nutrient content profile closest to that of cryoconite was found in the technogenic soils of the same region [41]. Based on this, it can be concluded that the organo-mineral substances accumulated in cryoconite are the least suitable for the development of plants and soil microbiota $[53,54]$. The low content of nutrients in cryoconites is due to the fact that birds prefer to nest in rocky outcrops and natural soils [41]. The accumulation of nutrients in cryoconites is an important factor in the functioning of local biomes. Cryoconites constitute a unique habitat in the cryosphere, where microbes have adapted to cold conditions. Research carried out in the Himalayas and Greenland confirms the fact that various microbes and fungi can live in cryoconites and form ecosystems within them [54]. Research carried out in Antarctica confirms the fact that bacteria that form on the continent (bacterial mats on land, sea ice, and melted ice from local ice sheets) are the source of bacterial communities in cryoconite holes [53]. Therefore, one of the sources of nitrogen compounds, in addition to birds, is the fixation of atmospheric nitrogen by bacteria and the creation of a nutrient base inside cryoconites. Liu et al. [55] provided the information about the mechanism of accumulation of $\mathrm{BC}$ and $\mathrm{PM}_{1}$ in living organisms of marine ecosystems (using the example of sea anemones that feed on suspended solids in sea water) in the Taiwan region. The author consider that $\mathrm{BC}$ and $\mathrm{PM}_{1}$ particles are able to freely overcome biological barriers. The paper cited also provides the evidence that the $\mathrm{BC}$ found in sea anemone organisms was obtained by biomass combustion as well as by weathering ancient rocks. The work also confirms the theory that $\mathrm{BC}^{\prime}$ 's nutrients are absorbed by marine organisms and can be included in the food chain, and these compounds can be passed on to their offspring [55]. So, due to the fact that BC with nutrients is consumed by organisms, trace metals in $\mathrm{BC}$ could transit the biological barrier and integrate into food chains by the same mechanism of transfer.

Thus, cryoconites are one of the few environments in Antarctica considered inhabitable by multicellular animals. Each cryoconite is inherently unique and can support a discrete ecosystem. In addition, the ability of $\mathrm{BC}$ to overcome biological barriers and enter to food chains can present a serious threat to living organisms and human health in unique Antarctic environments. 


\section{Conclusions}

BC plays a key role in climate change, particularly in deglaciation. Thus, it is necessary to comprehensively study it in the polar regions of the Earth. Together with $B C$, trace metals and nutrients are sequestered in cryoconites but can subsequently be released to the waters and soils of polar systems when snow and ice melt. In Antarctica, BC is sourced from research stations as well as from the weathering of parent rock. Most of the trace metals are transported there by the weathering of volcanic rocks. $\mathrm{Cd}$ and $\mathrm{Cu}$ are of anthropogenic origin, which apparently enter cryoconites during the transfer of contaminated soil and ground particles by wind. The nutrient content of cryoconites is closest to that of the contaminated soils of King George Island. It is currently impossible to create reliable models for the accumulation of $\mathrm{BC}$ on ice and snow surfaces. Further study of the qualitative and quantitative composition of $\mathrm{BC}$ in the atmosphere and on glaciers will contribute to the parametrization of the global carbon cycle as well as prevent water and soil pollution in the polar regions. Improving our knowledge of polar pollution is essential in this era of global change. Cryoconites found on the surface of glaciers are a secondary source of trace metals. When the edge of the glacier melts, the contaminated material is deposited in soil cover and marine sediments. Some trace metals tend to accumulate in biota and then be transported along the food chain. Thus, the importance of studying the migration, accumulation, and sources of trace metals in cryoconites is extremely important.

Author Contributions: B.M. performed the expedition with fieldwork and soil sampling; V.P. and E.A. wrote the paper. All authors have read and agreed to the published version of the manuscript.

Funding: This work was supported by the Grant of Russian Foundation for Basic Research No. No. 19-05-50107, 18-04-00900 and by the state task Russian Ministry of Education and Science № 0148-2019-0004.

Conflicts of Interest: The authors declare no conflict of interest.

\section{References}

1. Hirdman, D.; Sodemann, H.; Eckhardt, S.; Burkhart, J.F.; Jefferson, A.; Mefford, T.; Quinn, P.K.; Sharma, S.; Ström, J.; Stohl, A. Source identification of short-lived air pollutants in the Arctic using statistical analysis of measurement data and particle dispersion model output. Atmos. Chem. Phys. 2010, 10, 669-693. [CrossRef]

2. Schnell, R.C. Arctic haze and the Arctic Gas and Aerosol Sampling Program (AGASP). Geophys. Resear. Lett. 1984, 11, 361-364. [CrossRef]

3. Clarke, A.D.; Noone, K.J. Soot in the Arctic snowpack: A cause for perturbations in radiative transfer. Atmos. Environ. (1967) 1985, 19, 2045-2053. [CrossRef]

4. Quinn, P.K.; Bates, T.S.; Baum, E.; Bond, T.; Burkhart, J.F.; Fiore, A.M.; Flanner, M.; Garrett, T.J.; Koch, D.; McConnell, J.; et al. The Impact of Short-Lived Pollutants on Arctic Climate. AMAP Technical Report No. 1 (2008); Arctic Monitoring and Assessment Programme (AMAP): Oslo, Norway, 2010; p. 32.

5. AMAP. AMAP Assessment 2015: Black Carbon and Ozone as Arctic Climate Forcers; Arctic Monitoring and Assessment Programme (AMAP): Oslo, Norway, 2015; p. 116.

6. Derksen, C.; Brown, R. Spring snow cover extent reductions in the 2008-2012 period exceeding climate model projections. Geophys. Resear. Lett. 2012, 39. [CrossRef]

7. Brown, R.D.; Mote, P.W. The Response of Northern Hemisphere Snow Cover to a Changing Climate*. J. Clim. 2009, 22, 2124-2145. [CrossRef]

8. Stroeve, J.C.; Serreze, M.C.; Holland, M.M.; Kay, J.E.; Malanik, J.; Barrett, A.P. The Arctic's rapidly shrinking sea ice cover: A research synthesis. Clim. Chang. 2012, 110, 1005-1027. [CrossRef]

9. Hansen, J.; Nazarenko, L. Soot climate forcing via snow and ice albedos. Proc. Natl. Acad. Sci. USA 2004, 101, 423. [CrossRef]

10. Bond, T.C.; Doherty, S.J.; Fahey, D.W.; Forster, P.M.; Berntsen, T.; DeAngelo, B.J.; Flanner, M.G.; Ghan, S.; Kärcher, B.; Koch, D.; et al. Bounding the role of black carbon in the climate system: A scientific assessment. J. Geophys. Resear. Atmos. 2013, 118, 5380-5552. [CrossRef]

11. The Arctic Council. Expert Group on Black Carbon and Methane-Summary of Progress and Recommendations 2019; p. 88. Available online: https://globalmethane.org/challenge/arctic.html (accessed on 15 November 2020). 
12. Jacobson, M.Z. Strong radiative heating due to the mixing state of black carbon in atmospheric aerosols. Nature 2001, 409, 695-697. [CrossRef]

13. Brown, R.; Derksen, C.; Wang, L. A multi-data set analysis of variability and change in Arctic spring snow cover extent, 1967-2008. J. Geophys. Resear. Atmos. 2010, 115. [CrossRef]

14. Molina, M.; Zaelke, D.; Sarma, K.M.; Andersen, S.O.; Ramanathan, V.; Kaniaru, D. Reducing abrupt climate change risk using the Montreal Protocol and other regulatory actions to complement cuts in $\mathrm{CO}_{2}$ emissions. Proc. Natl. Acad. Sci. USA 2009, 106, 20616. [CrossRef] [PubMed]

15. Hegg, D.A.; Warren, S.G.; Grenfell, T.C.; Doherty, S.J.; Larson, T.V.; Clarke, A.D. Source Attribution of Black Carbon in Arctic Snow. Environ. Sci. Technol. 2009, 43, 4016-4021. [CrossRef] [PubMed]

16. Lamarque, J.F.; Bond, T.C.; Eyring, V.; Granier, C.; Heil, A.; Klimont, Z.; Lee, D.; Liousse, C.; Mieville, A.; Owen, B.; et al. Historical (1850-2000) gridded anthropogenic and biomass burning emissions of reactive gases and aerosols: Methodology and application. Atmos. Chem. Phys. 2010, 10, 7017-7039. [CrossRef]

17. Tunved, P.; Ström, J.; Krejci, R. Arctic aerosol life cycle: Linking aerosol size distributions observed between 2000 and 2010 with air mass transport and precipitation at Zeppelin station, Ny-Ålesund, Svalbard. Atmos. Chem. Phys. 2013, 13, 3643-3660. [CrossRef]

18. Stier, P.; Seinfeld, J.H.; Kinne, S.; Feichter, J.; Boucher, O. Impact of nonabsorbing anthropogenic aerosols on clear-sky atmospheric absorption. J. Geophys. Resear. Atmos. 2006, 111. [CrossRef]

19. Warneke, C.; Bahreini, R.; Brioude, J.; Brock, C.A.; De Gouw, J.A.; Fahey, D.W.; Froyd, K.D.; Holloway, J.S.; Middlebrook, A.; Miller, L.; et al. Biomass burning in Siberia and Kazakhstan as an important source for haze over the Alaskan Arctic in April 2008. Geophys. Resear. Lett. 2009, 36. [CrossRef]

20. Stone, R.S.; Sharma, S.; Herber, A.; Eleftheriadis, K.; Nelson, D.W. A characterization of Arctic aerosols on the basis of aerosol optical depth and black carbon measurements. Elem. Sci. Antropocene 2014, 000027. [CrossRef]

21. Łokas, E.; Zaborska, A.; Kolicka, M.; Różycki, M.; Zawierucha, K. Accumulation of atmospheric radionuclides and heavy metals in cryoconite holes on an Arctic glacier. Chemosphere 2016, 160, 162-172. [CrossRef]

22. Zwally, H.J.; Li, J.; Robbins, J.W.; Saba, J.L.; Yi, D.; Brenner, A.C. Mass gains of the Antarctic ice sheet exceed losses. J. Glaciol. 2017, 61, 1019-1036. [CrossRef]

23. Shepherd, A.; Ivins, E.R.; Geruo, A.; Barletta, V.R.; Bentley, M.J.; Bettadpur, S.; Briggs, K.H.; Bromwich, D.H.; Forsberg, R.; Galin, N.; et al. A Reconciled Estimate of Ice-Sheet Mass Balance. Science 2012, 338, 1183. [CrossRef]

24. Feldmann, J.; Levermann, A.; Mengel, M. Stabilizing the West Antarctic Ice Sheet by surface mass deposition. Sci. Adv. 2019, 5, eaaw4132. [CrossRef] [PubMed]

25. Shepherd, A.; Ivins, E.; Rignot, E.; Smith, B.; Van den Broeke, M.; Velicogna, I.; Whitehouse, P.; Briggs, K.; Joughin, I.; Krinner, G.; et al. Mass balance of the Antarctic Ice Sheet from 1992 to 2017. Nature 2018, 558, 219-222. [CrossRef]

26. Dutrieux, P.; Vaughan, D.G.; Corr, H.F.J.; Jenkins, A.; Holland, P.R.; Joughin, I.; Fleming, A.H. Pine Island glacier ice shelf melt distributed at kilometre scales. Cryosphere 2013, 7, 1543-1555. [CrossRef]

27. Dickens, W.A.; Kuhn, G.; Leng, M.J.; Graham, A.G.C.; Dowdeswell, J.A.; Meredith, M.P.; Hillenbrand, C.D.; Hodgson, D.A.; Roberts, S.J.; Sloane, H.; et al. Enhanced glacial discharge from the eastern Antarctic Peninsula since the 1700s associated with a positive Southern Annular Mode. Sci. Rep. 2019, 9, 14606. [CrossRef] [PubMed]

28. Akilan, A.; Abdul Azeez, K.K.; Schuh, H.; Padhy, S.; Kumar Kotluri, S. Perturbations in atmospheric gaseous components over coastal Antarctica detected in GPS signals and its natural origin to volcanic eruption. Polar Sci. 2019, 19, 69-76. [CrossRef]

29. Rignot, E.; Velicogna, I.; Van den Broeke, M.R.; Monaghan, A.; Lenaerts, J.T.M. Acceleration of the contribution of the Greenland and Antarctic ice sheets to sea level rise. Geophys. Resear. Lett. 2011, 38. [CrossRef]

30. Hara, K.; Sudo, K.; Ohnishi, T.; Osada, K.; Yabuki, M.; Shiobara, M.; Yamanouchi, T. Seasonal features and origins of carbonaceous aerosols at Syowa Station, coastal Antarctica. Atmos. Chem. Phys. 2019, 19, 7817-7837. [CrossRef]

31. Khan, A.L.; McMeeking, G.R.; Schwarz, J.P.; Xian, P.; Welch, K.A.; Berry Lyons, W.; McKnight, D.M. Near-Surface Refractory Black Carbon Observations in the Atmosphere and Snow in the McMurdo Dry Valleys, Antarctica, and Potential Impacts of Foehn Winds. J. Geophys. Resear. Atmos. 2018, 123, 2877-2887. [CrossRef]

32. Gogoi, M.M.; Babu, S.S.; Pandey, S.K.; Nair, V.S.; Vaishya, A.; Girach, I.A.; Koushik, N. Scavenging ratio of black carbon in the Arctic and the Antarctic. Polar Sci. 2018, 16, 10-22. [CrossRef] 
33. Selby, M.J. Antarctica: Soils, weathering processes and environment, I. B. Campbell and G. G. C. Claridge, (developments in soil science 16), Elsevier, Amsterdam, 1987. No. of pages: 368. Earth Surf. Process. Landf. 1989, 14, 753-754. [CrossRef]

34. Singh, S.M.; Sharma, J.; Gawas-Sakhalkar, P.; Upadhyay, A.K.; Naik, S.; Pedneker, S.M.; Ravindra, R. Atmospheric deposition studies of heavy metals in Arctic by comparative analysis of lichens and cryoconite. Environ. Monit. Assess. 2013, 185, 1367-1376. [CrossRef] [PubMed]

35. Hong, S.; Lluberas, A.; Lee, G.; Park, J.K. Natural and Anthropogenic Heavy Metal Deposition to the Snow in King George Island, Antarctic Peninsula. Ocean Polar Resear. 2002, 24, 279-287. [CrossRef]

36. Hans Wedepohl, K. The composition of the continental crust. Geochim. Cosmochim. Acta 1995, 59, 1217-1232. [CrossRef]

37. Santos, I.R.; Silva-Filho, E.V.; Schaefer, C.E.G.R.; Albuquerque-Filho, M.R.; Campos, L.S. Heavy metal contamination in coastal sediments and soils near the Brazilian Antarctic Station, King George Island. Mar. Pollut. Bull. 2005, 50, 185-194. [CrossRef] [PubMed]

38. De Lima Neto, E.; Guerra, M.B.B.; Thomazini, A.; Daher, M.; De Andrade, A.M.; Schaefer, C.E.G.R. Soil Contamination by Toxic Metals Near an Antarctic Refuge in Robert Island, Maritime Antarctica: A Monitoring Strategy. Water Air Soil Pollut. 2017, 228, 66. [CrossRef]

39. Casey, K.A.; Kaspari, S.D.; Skiles, S.M.; Kreutz, K.; Handley, M.J. The spectral and chemical measurement of pollutants on snow near South Pole, Antarctica. J. Geophys. Resear. Atmos. 2017, 122, 6592-6610. [CrossRef]

40. Baccolo, G.; Nastasi, M.; Massabò, D.; Clason, C.; Di Mauro, B.; Di Stefano, E.; Łokas, E.; Prati, P.; Previtali, E.; Takeuchi, N.; et al. Artificial and natural radionuclides in cryoconite as tracers of supraglacial dynamics: Insights from the Morteratsch glacier (Swiss Alps). Catena 2020, 191, 104577. [CrossRef]

41. Abakumov, E. Content of available forms of nitrogen, potassium and phosphorus in ornithogenic and other soils of the Fildes Peninsula (King George Island, Western Antarctica). Biol. Commun. 2008, 63, 109-116. [CrossRef]

42. Hegg, D.A.; Warren, S.G.; Grenfell, T.C.; Sarah, J.D.; Clarke, A.D. Sources of light-absorbing aerosol in arctic snow and their seasonal variation. Atmos. Chem. Phys. 2010, 10, 10923-10938. [CrossRef]

43. ISO 11047:1998, Soil Quality-Determination of Cadmium, Cobalt, Copper, Lead, Manganese, Nickel and Zinc in Aqua Regia Extracts of Soil-Flame and Electrothermal Atomic Absorption Spectrometric Methods. 1998, p. 18. Available online: https://www.iso.org/standard/24010.html (accessed on 15 November 2020).

44. ISO 14256-1:2003, Soil quality-Determination of nitrate, nitrite and ammonium in field moist soils by extraction with potassium chloride solution_Part 1: Manual method (ISO/TS 14256-1-2003:2003). 2003, p. 14. Available online: https://www.iso.org/standard/36706.html (accessed on 15 November 2020).

45. 54650-2011, Determination of mobile phosphorus and potassium compounds by Kirsanov method modified by CINAO. 2011, p. 9. Available online: http://docs.cntd.ru/document/gost-r-54650-2011 (accessed on 15 November 2020).

46. Groenewerg, W.J.; Beunk, F. The petrography and geochemistry of the King George Island Supergroup and the Admiralty Bay Group volcanics, South Shetland Islands. Available online: http://polardigital.igme.es/ handle/123456789/1612 (accessed on 15 November 2020).

47. Amaro, E.; Padeiro, A.; Mão de Ferro, A.; Mota, A.M.; Leppe, M.; Verkulich, S.; Hughes, K.A.; Peter, H.-U.; Canário, J. Assessing trace element contamination in Fildes Peninsula (King George Island) and Ardley Island, Antarctic. Mar. Pollut. Bull. 2015, 97, 523-527. [CrossRef]

48. Braga Bueno Guerra, M.; Schaefer, C.E.G.R.; De Freitas Rosa, P.; Simas, F.N.B.; Pereira, T.T.C.; Rodrigues Pereira-Filho, E. Heavy Metals Contamination in Century-Old Manmade Technosols of Hope Bay, Antarctic Peninsula. Water Air Soil Pollut. 2011, 222, 91-102. [CrossRef]

49. Celis, J.E.; Barra, R.; Espejo, W.; González-Acuña, D.; Jara, S. Trace Element Concentrations in Biotic Matrices of Gentoo Penguins (Pygoscelis Papua) and Coastal Soils from Different Locations of the Antarctic Peninsula. Water Air Soil Pollut. 2014, 226, 2266. [CrossRef]

50. Crockett, A.B. Background Levels of Metals in Soils, McMurdo Station, Antarctica. Environ. Monit. Assess. 1998, 50, 289-296. [CrossRef] [PubMed]

51. Jiao, X.; Dong, Z.; Kang, S.; Li, Y.; Jiang, C.; Rostami, M. New insights into heavy metal elements deposition in the snowpacks of mountain glaciers in the eastern Tibetan Plateau. Ecotoxicol. Environ. Saf. 2021, 207, 111228. [CrossRef] [PubMed]

52. Shaw, G.E. Evidence for a central Eurasian source area of Arctic haze in Alaska. Nature 1982, 299, 815-818. [CrossRef]

53. Christner, B.C.; Kvitko, B.H.; Reeve, J.N. Molecular identification of Bacteria and Eukarya inhabiting an Antarctic cryoconite hole. Extremophiles 2003, 7, 177-183. [CrossRef] 
54. Singh, P.; Tsuji, M.; Singh, S.M.; Takeuchi, N. Contrasting Patterns of Microbial Communities in Glacier Cryoconite of Nepali Himalaya and Greenland, Arctic. Sustainability 2020, 12, 6477. [CrossRef]

55. Liu, L.; Hsieh, C.; Kuo, M.; Chen, C.; Shau, Y.; Lui, H.; Yuan, C.; Arthur Chen, C. Evidence for Fossil Fuel $\mathrm{PM}_{1}$ Accumulation in Marine Biota. Environ. Sci. Technol. 2020, 54, 7, 4068-4078. [CrossRef]

Publisher's Note: MDPI stays neutral with regard to jurisdictional claims in published maps and institutional affiliations.

(C) 2020 by the authors. Licensee MDPI, Basel, Switzerland. This article is an open access article distributed under the terms and conditions of the Creative Commons Attribution (CC BY) license (http://creativecommons.org/licenses/by/4.0/). 